\title{
Global view of sea-ice production in polynyas and its linkage to dense/bottom water formation
}

\author{
Kay I. Ohshima ${ }^{1 *}$, Sohey Nihashi ${ }^{2}$ and Katsushi Iwamoto ${ }^{3}$
}

\begin{abstract}
Global overturning circulation is driven by density differences. Saline water rejected during sea-ice formation in polynyas is the main source of dense water, and thus sea-ice production is a key factor in the overturning circulation. Due to difficulties associated with in situ observation, sea-ice production and its interannual variability have not been well understood until recently. Methods to estimate sea-ice production on large scales have been developed using heat flux calculations based on satellite microwave radiometer data. Using these methods, we present the mapping of seaice production with the same definition and scale globally, and review the polynya ice production and its relationship with dense/bottom water. The mapping demonstrates that ice production rate is high in Antarctic coastal polynyas, in contrast to Arctic coastal polynyas. This is consistent with the formation of Antarctic Bottom Water (AABW), the densest water mass which occupies the abyssal layer of the global ocean. The Ross Ice Shelf polynya has by far the highest ice production in the Southern Hemisphere. The Cape Darnley polynya $\left(65^{\circ} \mathrm{E}-69^{\circ} \mathrm{E}\right)$ is found to be the second highest production area and recent observations revealed that this is the missing (fourth) source of AABW. In the region off the Mertz Glacier Tongue (MGT), the third source of AABW, sea-ice production decreased by as much as $40 \%$, due to the MGT calving in early 2010, resulting in a significant decrease in AABW production. The Okhotsk Northwestern polynya exhibits the highest ice production in the Northern Hemisphere, and the resultant dense water formation leads to overturning in the North Pacific, extending to the intermediate layer. Estimates of its ice production show a significant decrease over the past 30-50 years, likely causing the weakening of the North Pacific overturning. These regions demonstrate the strong linkage between variabilities of sea-ice production and bottom/intermediate water formation. The mapping has also provided surface boundary conditions and validation data of heat- and salt-flux associated with sea-ice formation/melting for various ocean and coupled models.
\end{abstract}

Keywords: Sea-ice production, Dense water, Antarctic Bottom Water, Okhotsk Sea Intermediate Water, Coastal polynya, Overturning, Microwave radiometer, AMSR-E

\section{Background}

Global overturning circulation is driven by density differences: water sinks in dense water formation areas and then gradually upwells in other areas. Deep water in the world originates from two formation areas: the North Atlantic and Southern Ocean, and the resulting dense water masses are termed North Atlantic Deep Water

\footnotetext{
*Correspondence: ohshima@lowtem.hokudai.ac.jp

${ }^{1}$ Institute of Low Temperature Science, Hokkaido University, Sapporo, Japan

Full list of author information is available at the end of the article
}

(NADW) and Antarctic Bottom Water (AABW), respectively. Sinking of these two dense water masses drives the thermohaline circulation (overturning) on a timescale of $1000-2000$ years. NADW can be produced only by the cooling of saline water advected from the Gulf Stream, without sea-ice formation. By contrast, for production of AABW, sea-ice formation is essential.

When sea ice is formed, most of the salt content (70$90 \%$ ) is rejected from the ice and thus cold and saline water (brine) is released into the ocean below. The colder the seawater or the higher its salt content, the denser it becomes. Saline water rejected during sea-ice formation 
is the main source of dense water. AABW originates as dense shelf water (DSW), which forms on the continental shelf by regionally varying combinations of brine rejection from sea-ice production and ocean/ice-shelf interactions (Orsi et al. 1999). AABW is the densest water mass in the world's abyssal layer, accounting for 30-40\% of the global ocean mass (Johnson 2008). Thus, AABW production represents an important sink for heat and possibly $\mathrm{CO}_{2}$ (Sigman and Boyle 2000). Although dense water that can reach the deep layer is not produced in the North Pacific, dense water that reaches the intermediate layer (about 200-800 $\mathrm{m}$ deep) can be produced by sea-ice formation in the Sea of Okhotsk (Shcherbina et al. 2003). Sinking of this dense water creates overturning down to intermediate depths in the North Pacific (Warner et al. 1996). Therefore, where and how much sea-ice formation occurs is a key factor in the global overturning circulation.

High ice production and subsequent dense water formation occur in limited areas known as coastal (or latent heat) polynyas, which are thin ice or open water areas formed by divergent ice motion due to prevailing winds and/or oceanic currents (Morales Maqueda et al. 2004; Gordon and Comiso 1988). The length scale of the polynya in the downwind direction, typically $10-100 \mathrm{~km}$, is set by a balance between the production of new ice within the polynya, its export downwind to the pack ice edge, and the subsequent upwind growth of the piled up new ice (Pease 1987; Martin 2001). Since the insulating effect of sea ice is very sensitive to ice thickness, heat loss in regions of thin ice is one or two orders of magnitude greater than that in thicker ice regions in winter. During winter, coastal polynyas are regarded as important ice production factories and sites of dense water formation, through the brine rejection process.

Due to logistical difficulties in in situ polynya observations, sea-ice production and its interannual variability have not been well understood. Detection of coastal polynyas on large scales has been achieved using satellite microwave radiometer data, which are available globally regardless of darkness or cloud cover. In sea-ice concentration algorithms, coastal polynyas are generally shown as low ice concentration areas. Cavalieri and Martin (1985) and Massom et al. (1998) showed the distribution of coastal polynyas, defined as recurring low ice concentration areas in East Antarctica. Cavalieri and Martin (1994) showed the distribution of coastal polynyas similarly for the Arctic Ocean and Bering Sea. A map of coastal polynya all over the world (Martin 2001) was based on these studies. Under winter conditions, however, open water in coastal polynyas often freezes very rapidly. Thus, most of the polynya area in winter is covered with thin ice, except within about $1 \mathrm{~km}$ from the coastline in winter. With $6-50 \mathrm{~km}$ resolution (depending on sensor and frequency) microwave radiometer data, the open water in a coastal polynya is usually too small to be resolved; hence coastal polynyas should be identified as areas of thin ice, not as areas of low ice concentration.

Recently algorithms that detect thin-ice areas and estimate ice thickness have been developed. Once the ice thickness is obtained, ice production can be inferred from the calculation of surface heat flux. Such an investigation has been made independently for each polar ocean. In this paper, we present the mapping of coastal polynya and ice production, using the AMSR-E algorithm developed by Nihashi and Ohshima (2015) for the Southern Hemisphere and by Iwamoto et al. (2014) for the Northern Hemisphere, with the same definition and scale for both hemispheres. Based on this unified presentation, we review the polynya ice production and its relationship with bottom/intermediate water from the global view. The mapping has led to the discovery of unknown formation areas of $A A B W$ and elucidation of strong linkage between seaice production and bottom/intermediate water formation and their variabilities.

\section{Microwave radiometer algorithm for sea-ice thickness and production estimation}

The most effective means of detection of thin-ice area and estimation of sea-ice production on large scales is satellite remote sensing using passive microwave sensors, e.g., the Special Sensor Microwave/Imager (SSM/I) and Special Sensor Microwave Imager/Sounder, operating between 1987 and the present, Advanced Microwave Scanning Radiometer-Earth Observing System (AMSR-E), which operated between 2003 and 2011, and Advanced Microwave Scanning Radiometer 2, operating between 2012 and the present. This is based upon their ability to gain complete polar coverage on a daily basis irrespective of clouds and darkness.

The microwave (SSM/I) algorithm that discriminates thin ice from thick ice was first proposed by Cavalieri (1994) for the Bering Sea, followed by Martin et al. (1998) for the Sea of Okhotsk. To estimate thin-ice thickness specifically, the polarization ratio $(\mathrm{PR})$ has been generally used, where $\mathrm{PR}$ is defined as $\left(\mathrm{TB}_{\mathrm{V}}-\mathrm{TB}_{\mathrm{H}}\right) /\left(\mathrm{TB}_{\mathrm{V}}+\mathrm{TB}_{\mathrm{H}}\right)$ with $\mathrm{TB}_{V}$ and $\mathrm{TB}_{H}$ being the vertically and horizontally polarized brightness temperature (TB), respectively. This is because PR is negatively correlated with ice thickness of $<\sim 0.2 \mathrm{~m}$ (Hwang et al. 2007). It has been shown that the salinity of the ice surface is strongly correlated with thin-ice thickness, suggesting that the negatively correlated relationship between the PR and ice thickness is primarily caused by the ice surface salinity (Cox and Weeks 1974; Toyota et al. 2007). 
A thin-ice thickness algorithm has been developed from comparisons between the PR and ice thickness. The ice thickness is derived from heat flux calculations using ice surface temperatures from satellite thermal infrared images, such as the Advanced Very High-Resolution Radiometer (AVHRR) and the Moderate Resolution Imaging Spectroradiometer (MODIS), with ECMWF or NCEP atmospheric data. A procedure of the algorithm construction is schematically shown in the upper part of Fig. 1.

Most algorithms have used the thermal ice thickness for which the calculated total heat flux using infrared (AVHRR or MODIS) data would be realized under the assumption of uniform ice thickness in the microwave (SSM/I or AMSR-E) footprint (Drucker et al. 2003; Tamura et al. 2007). The thermal ice thickness does not exactly coincide with the arithmetic average of the thicknesses that are calculated at infrared data pixels within the microwave data footprint. This thermal ice thickness is suitable for heat loss calculation in the estimation of ice production.

To date, and based on the above relationships, several algorithms have been developed for estimating thin-ice thickness up to 0.1-0.2 $\mathrm{m}$ from SSM/I (Martin et al. 2004; Tamura et al. 2007; Tamura and Ohshima 2011) and from AMSR-E (Nihashi et al. 2009; Iwamoto et al. 2013; Scott et al. 2014; Nihashi and Ohshima 2015). It should be noted that microwave radiometer can only detect thin ice of $<\sim 0.2 \mathrm{~m}$ and thicker ice should be measured by other ways such as satellite laser or radar altimetry (e.g., Kurtz and Markus 2012).

The thin-ice thickness retrieval algorithm generally uses two frequencies: 37 and $85 \mathrm{GHz}$ for SSM/I, and 36 and $89 \mathrm{GHz}$ for AMSR-E. Although the higher frequency $(85$ or $89 \mathrm{GHz}$ ) data have higher spatial resolution, they tend to be affected by water vapor and cloud liquid water content in the atmosphere, especially in relatively warm conditions. To minimize such problems, a water vapor correction is proposed and 85 or $89 \mathrm{GHz}$ data contaminated by water vapor are removed (Tamura et al. 2007; Iwamoto et al. 2013).

Another problem is the misinterpretation of the signal from ice shelves, landfast ice, and icebergs as that from areas of thin ice. These types of ice generally exist adjacent to coastal polynyas, and their microwave characteristics can be similar to those of thin ice. To overcome this problem in the Antarctic, ice shelves, landfast ice, and icebergs are discriminated from thin sea ice by using a scatter plot of vertical versus horizontal polarization brightness temperatures (TBs) (Tamura et al. 2007, 2015; Nihashi and Ohshima 2015). The TB signatures of ice shelves, landfast ice, and icebergs are similar to that of the ice sheet on the scatter plot.

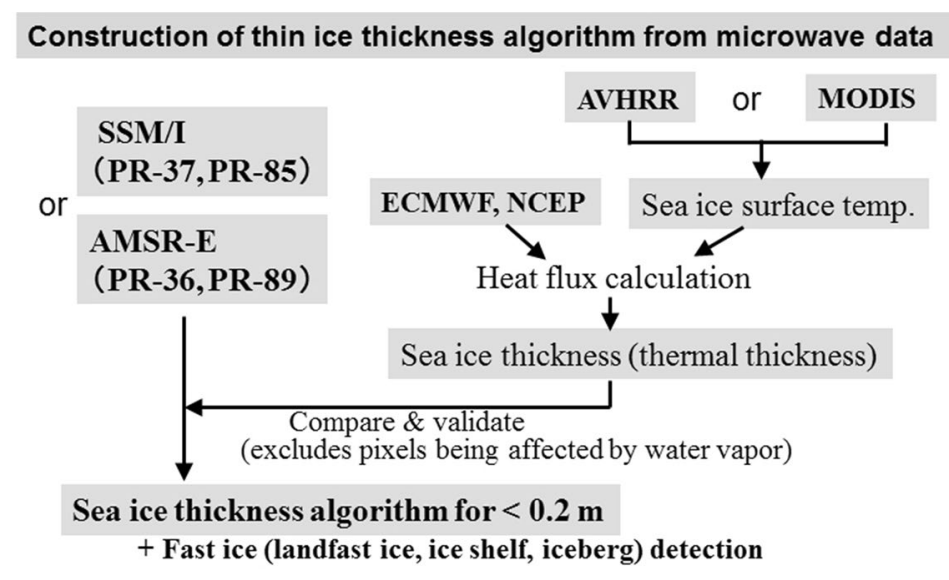

Creation of value-added sea-ice product from passive microwave

Thin ice thickness algorithm of SSM/I or AMSR-E

Calculation of heat flux from the estimated ice thickness

2

Estimate of sea ice production assuming no oceanic heat

Estimate of salt flux due to brine rejection by ice production

Fig. 1 Schematics for (upper part) construction of thin-ice thickness algorithm and (lower part) creation of value-added product from the algorithm 
The mapped spatial resolution of AMSR-E is about $6.25 \mathrm{~km}$ at $89 \mathrm{GHz}$ and about $12.5 \mathrm{~km}$ at $36 \mathrm{GHz}$. The pixel density of AMSR-E is four times higher than that of SSM/I. This advantage of AMSR-E is critical for the monitoring of coastal polynyas because of their fairly small areal extent (i.e., from 10 to $100 \mathrm{~km}$ at most). To obtain the spatial distribution of thin-ice thickness, combined use of two frequency channel data is often exploited. For the case of AMSR-E, $89 \mathrm{GHz}$ data are first used for the thinner range (e.g., $0-0.1 \mathrm{~m}$ ) and then $36 \mathrm{GHz}$ data for the thicker range (e.g., $0.1-0.2 \mathrm{~m}$ ). The false thin-ice signals over landfast ice areas are mostly eliminated by this method. This method is expected to enable retention of the finer resolution of $89 \mathrm{GHz}$ data near the coast and landfast ice, because they are preferentially used for the thinner ice area.

For detection of coastal polynyas from microwave data, a completely different algorithm has been also developed by Markus and Burns (1995). This algorithm, named as the Polynya Signature Simulation Method (PSSM), is based on simulating microwave images of polynya events by convolving an assumed brightness temperature distribution with the satellite antenna pattern. Based on the PSSM algorithm, the circumpolar mapping of the Antarctic coastal polynyas was presented by Arrigo and van Dijken (2003) and Kern (2009), and that of the Northern Hemisphere polynyas by Barber and Massom (2007). The advantages of the PSSM algorithm are its ability to correct for atmospheric effects and its higher spatial resolution.

By using satellite-derived ice thickness data, ice production over thin-ice areas can be estimated from heat budget analysis, assuming that all of the heat loss goes into ice formation (lower part of Fig. 1). We first assume that the sum of radiative and turbulent fluxes at the ice surface is equal to the conductive heat flux in the ice, whose thickness is derived from the thin-ice algorithm. Using the empirical formula of the radiative and turbulent fluxes, the ice surface temperature can be solved. Then the heat loss can be obtained as the conductive heat flux. In this way, mapping of sea-ice production has been made, for the first time by Ohshima et al. (2003) with SSM/I in the Sea of Okhotsk, followed by a series of papers; for the Southern Ocean with SSM/I (Tamura et al. 2008) and AMSR-E (Nihashi and Ohshima 2015); for the Arctic Ocean with SSM/I (Tamura and Ohshima 2011) and AMSR-E (Iwamoto et al. 2014); and for the Sea of Okhotsk with AMSR-E (Nihashi et al. 2009, 2012) and SSM/I (Kashiwase et al. 2014). If there is oceanic heat flux from below, calculated ice production will be overestimated. Therefore, these mappings provide the upper bound of sea-ice production.
In this review, we introduce the mapping of coastal polynya, using the AMSR-E thin-ice thickness and fast-ice detection algorithms by Nihashi and Ohshima (2015) for the Southern Hemisphere, and the AMSRE thin-ice thickness algorithm by Iwamoto et al. (2014) for the Northern Hemisphere. Both thin-ice thickness algorithms adopt an exponential curve which best fits into the scatterplot of the PR versus thermal ice thickness. Although the algorithm by Iwamoto et al. (2014) was derived from the Arctic coastal polynyas, this algorithm is assumed to be applicable to the entire Northern Hemisphere in this paper. Further, the mapping of ice production is presented based on the ice thickness by these algorithms and near-surface atmospheric data from the ECMWF interim reanalysis dataset. The results presented here are basically identical to those by Nihashi and Ohshima (2015) and Iwamoto et al. (2014). According to the PR-thickness scatterplots, both thin-ice thickness algorithms contain an error of $\sim 5-6 \mathrm{~cm}$ at maximum. For estimation of ice production in both hemispheres, the largest ambiguity arises from the ice thickness data, by $\sim 30 \%$ at maximum.

\section{Mapping of coastal polynyas and sea-ice production}

\section{Southern Hemisphere}

Antarctic Bottom Water (AABW) originates from dense shelf water (DSW), which forms on the continental shelf by brine rejection from sea-ice formation. To generate sufficient negative buoyancy for the production of $\mathrm{AABW}$, a storage mechanism of rejected brine to increase the DSW density is also necessary. The Weddell and Ross Seas have large continental embayments associated with major continental ice shelves, providing the storage mechanism (Foldvik et al. 2004). The region off the Adélie Coast has a large depression which provides sufficient storage of DSW (Williams et al. 2008). These three regions were considered as the main production areas of AABW. The circumpolar total of DSW ventilation rate, that is the volume flux of DSW exported from the continental shelf that ultimately produces AABW, is estimated to be about $5.4 \mathrm{~Sv}\left(1 \mathrm{~Sv}=10^{6} \mathrm{~m}^{3} \mathrm{~s}^{-1}\right)$ based on chlorofluorocarbon data (Orsi et al. 2002). These DSWs mix down the continental slope with overlying Circumpolar Deep Water to produce AABW, increasing its volume. Thereby the total AABW production rate is estimated to be $15-20 \mathrm{~Sv}$, consisting of $50-60 \%$ in the Weddell Sea, $30-40 \%$ in the Ross Sea, and the remaining $10 \%$ off the Adélie Coast (Orsi et al. 2002). However, the estimation is approximate and the origins of DSWs and their volumes have not been well identified.

High ice production in a coastal polynya can produce DSW that contributes to AABW formation. The Ross 
Ice Shelf polynya and Terra Nova Bay polynya are identified as source areas of Ross Sea Bottom Water (Fusco et al. 2009; Comiso et al. 2011) and the Mertz polynya is identified as the source of Adélie Land Bottom Water (Williams et al. 2008). Mapping of coastal polynya and sea-ice production would provide valuable information to identify DSW that contributes to AABW formation and to estimate its volume. Regarding the ice production estimates using microwave data in the Southern Ocean, some regional studies have been undertaken along the Antarctic Wilkes Land coast (e.g., Cavalieri and Martin 1985), along the Weddell Sea coast (e.g., Markus et al. 1998), and in the Ross Sea (Martin et al. 2007; Comiso et al. 2011); Tamura et al. (2008) mapped sea-ice production over the entire Southern Ocean for the first time. According to this study, about $10 \%$ of sea ice is produced in the major coastal polynyas, although the total area of the polynyas is only about $1 \%$ of the maximum sea-ice area.

Figure 2 shows the frequency of occurrence of coastal polynyas and landfast ice based on the AMSR-E thin-ice thickness and fast-ice detection algorithms by Nihashi and Ohshima (2015). This mapping was the first combined circumpolar mapping of Antarctic coastal polynyas and landfast ice. The combined map clearly reveals their close relationship: large polynyas, the Cape Darnley, Barrier, Shackleton, Vincennes Bay, Dalton, Dibble, and Amundsen polynyas are formed on the western (lee) side of landfast ice, while the Mertz and Terra Nova Bay polynyas are formed adjacent to glacier tongues with fast ice. These findings suggest that landfast ice and glacier tongues are essential elements for the formation of most Antarctic coastal polynyas. Comparison with the wind data suggests that wind diverging from a boundary comprising both coastline and fast ice is the primary determinant of polynya formation (Nihashi and Ohshima 2015). The blocking effect of fast ice on westward sea-ice advection by the coastal current is another key factor.

A map of annual sea-ice production is shown in Fig. 3, based on Nihashi and Ohshima (2015). Although the spatial features of Figs. 2 and 3 are generally consistent with other studies from SSM/I (Arrigo and van Dijken 2003; Tamura et al. 2008), the AMSR-E can reveal more detailed spatial distribution, with fast ice being better resolved. Table 1 lists the annual ice production for the 13 major Antarctic polynyas. The Ross Ice Shelf polynya has by far the highest ice production. This is consistent with the fact that $\mathrm{AABW}$ with the highest salinity is formed in the Ross Sea (Orsi et al. 1999). By contrast, in the Weddell Sea (Ronne Ice Shelf polynya), which is a major source region of AABW formation, ice production is not prominent. This contrast is partly caused by the difference in prevailing wind direction (Drucker et al.
2011; Nakata et al. 2015). What we found in the mapping is that the second highest production is in the Cape Darnley polynya $\left(65^{\circ} \mathrm{E}-69^{\circ} \mathrm{E}\right)$, located west of the Amery Ice Shelf. The third highest is the Mertz polynya, which produces DSW as an ingredient of Adélie Land Bottom Water (Rintoul 1998). High ice production polynyas are concentrated in East Antarctica $\left(40^{\circ} \mathrm{E}-160^{\circ} \mathrm{E}\right)$, where more than the half of the total ice production occurs.

Since high ice production is the primary condition for the formation of DSW or AABW, this mapping suggests an investigation of the less-observed area of the Cape Darnley polynya as a possible AABW formation area. Motivated by the first mapping by Tamura et al. (2008), the Japanese program of the International Polar Year 2007-2008 planned to focus on this polynya. Then the mooring observations discovered overflows of newly formed AABW, bottom-intensified, cascading down the canyons north of Cape Darnley (Ohshima et al. 2013). This fourth type of AABW is termed Cape Darnley Bottom Water (CDBW). High salinity DSW, which can be a source of CDBW, was also observed over the shelf off Cape Darnley, from the instrumented seal data, which has recently become an important source of hydrographic profiles in logistically challenging regions/seasons around the Antarctic margin. Based on the mooring observations and a salinity budget from satellite-derived ice production, it is proposed that DSW of $0.3-0.7 \mathrm{~Sv}$ is ventilated in this region. This corresponds to $6-13 \%$ of the circumpolar DSW ventilation rate of $5.4 \mathrm{~Sv}$ (Orsi et al. 2002). CDBW migrates westward and increases its volume by gradual mixing with overlying Circumpolar Deep Water, to ultimately constitute part of the AABW in the Weddell Gyre. The contribution of CDBW is estimated to be about $15-30 \%$ of the AABW production in the Weddell Gyre. This is consistent with the result of the box inverse model (Jullion et al. 2014): up to $30 \%$ of the $\mathrm{AABW}$ in the Weddell Gyre is imported from the Indian Ocean sector, likely the Cape Darnley region.

The Cape Darnley region demonstrates that a relatively narrow section of continental shelf with limited DSW storage capacity can produce AABW from polynyadriven sea-ice production alone. This suggests that there could be further AABW-formation discoveries in similar polynyas, particularly those in East Antarctica. It is suggested that DSW formed in the Vincennes Bay polynya (the sixth highest ice production area from Table 1) contributes to the upper layer of AABW in Australian-Antarctic Basin (Kitade et al. 2014), although its volume and density is less compared to CDBW.

\section{Northern Hemisphere}

Although bottom water is not considered to be formed in the Arctic Ocean, dense water originating from the 


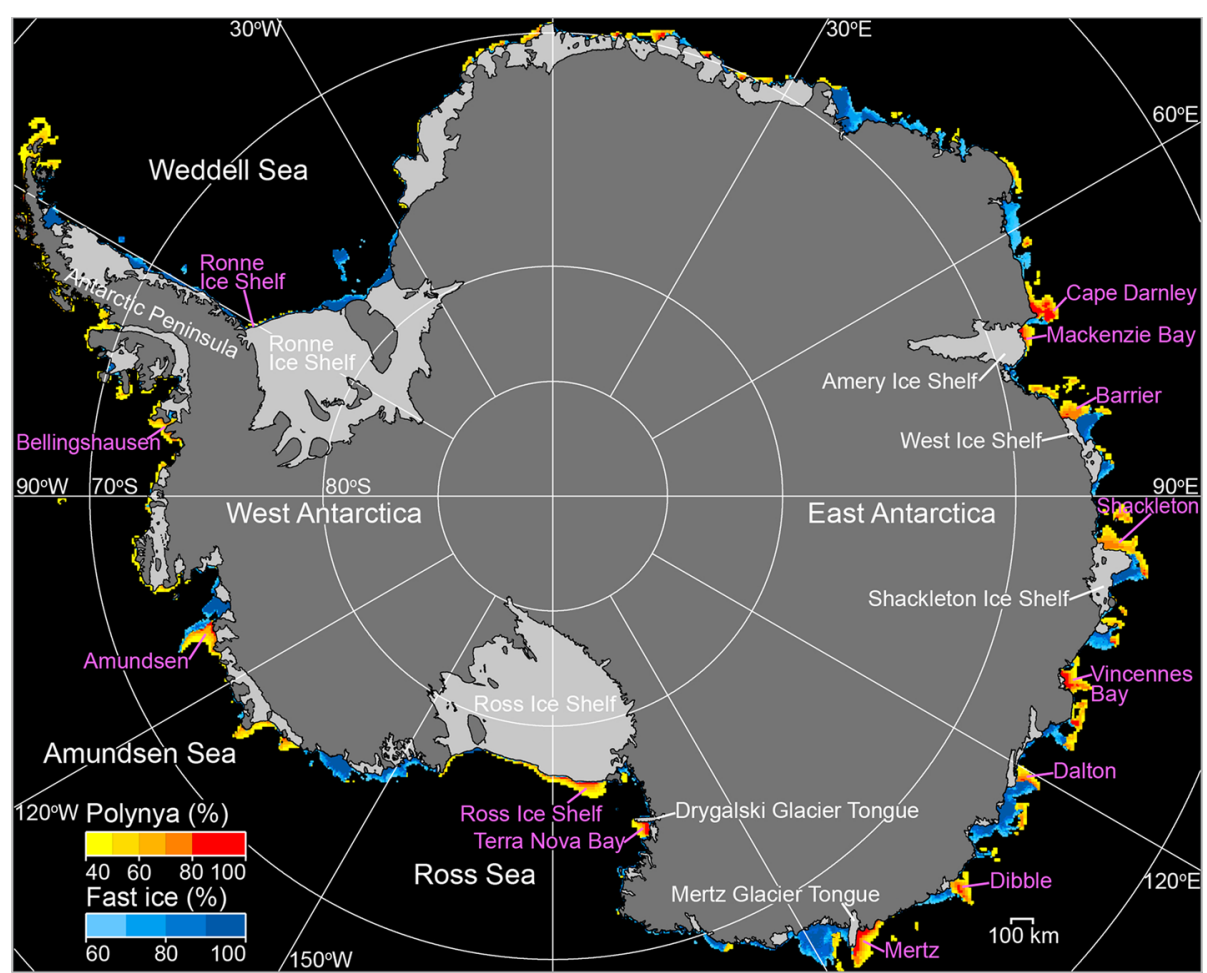

Fig. 2 Map of coastal polynyas and landfast sea ice in the Southern Hemisphere. The calculation is based on thin-ice thickness and fast ice detection algorithms of AMSR-E (Nihashi and Ohshima 2015). Frequency of occurrence during the freezing period (March-October) for the period of 2003-11 (March-September only for 2011) is shown by color shadings. The Antarctic continent and islands are indicated by gray, and ice shelves and glacier tongues are indicated by light gray

high ice production in the coastal polynyas intrudes the subsurface and maintains the cold halocline layer, which is a major subsurface water mass in the Arctic Ocean (Aagaard et al. 1981; Winsor and Bjork 2000); Cavalieri and Martin (1994) showed the distribution of coastal polynyas as reduced ice concentration areas for the Arctic Ocean and Bering Sea and discussed the contribution of the Chukchi, Bering, Beaufort, and Barents Sea polynyas to the cold halocline layer of the Arctic Ocean. Martin et al. (1998) showed the distribution of coastal polynyas in the Sea of Okhotsk and discussed their contribution to the Okhotsk Sea Intermediate Water and further to the North Pacific Intermediate Water.

The frequency of occurrence of coastal polynyas in the Northern Hemisphere (Fig. 4) is shown in the same color scale as that of Fig. 2, based on the AMSR-E thinice algorithm by Iwamoto et al. (2014). In contrast to the Southern Ocean, polynya activity is much weaker in the Arctic Ocean, because the Arctic Ocean is surrounded by lands and thus divergent ice motion is greatly suppressed. Instead, relatively large coastal polynyas occur in the marginal seas, the Bering, Okhotsk, and Barents Seas, where the adjacent ice edge provides room for ice divergence.
The annual cumulative ice production in the Northern Hemisphere (Fig. 5) is shown in the same color scale as that of Fig. 3. The ice production is estimated only in shallow shelf regions $(<500 \mathrm{~m})$ to avoid the effect of oceanic heat from below. In the Arctic Ocean, high ice production is largely confined to the major Arctic coastal polynyas: the North Water (NOW), Chukchi polynyas, and along the coasts of Novaya Zemlya, Franz Josef Land. Among the major polynyas, the NOW polynya has by far the highest ice production (Table 1), although it may be overestimated because the oceanic heat flux from the underlying warmer water partly contributes to the polynya occurrence (Steffen 1986). Most polynya regions exhibit maximum ice production in autumn (OctoberNovember), before areas offshore have been covered with consolidated pack ice, and then gradual decreasing production toward March (Tamura et al. 2012; Iwamoto et al. 2014). The areas offshore from these polynyas are covered with heavy pack ice in midwinter, and thus offshore-ward expansion of these polynyas could be limited.

In the Bering Sea, large polynyas occur in the Anadyr Gulf and south of St. Lawrence Island. The combined cumulative ice production becomes the second or third highest in the Northern Hemisphere (Table 1). 


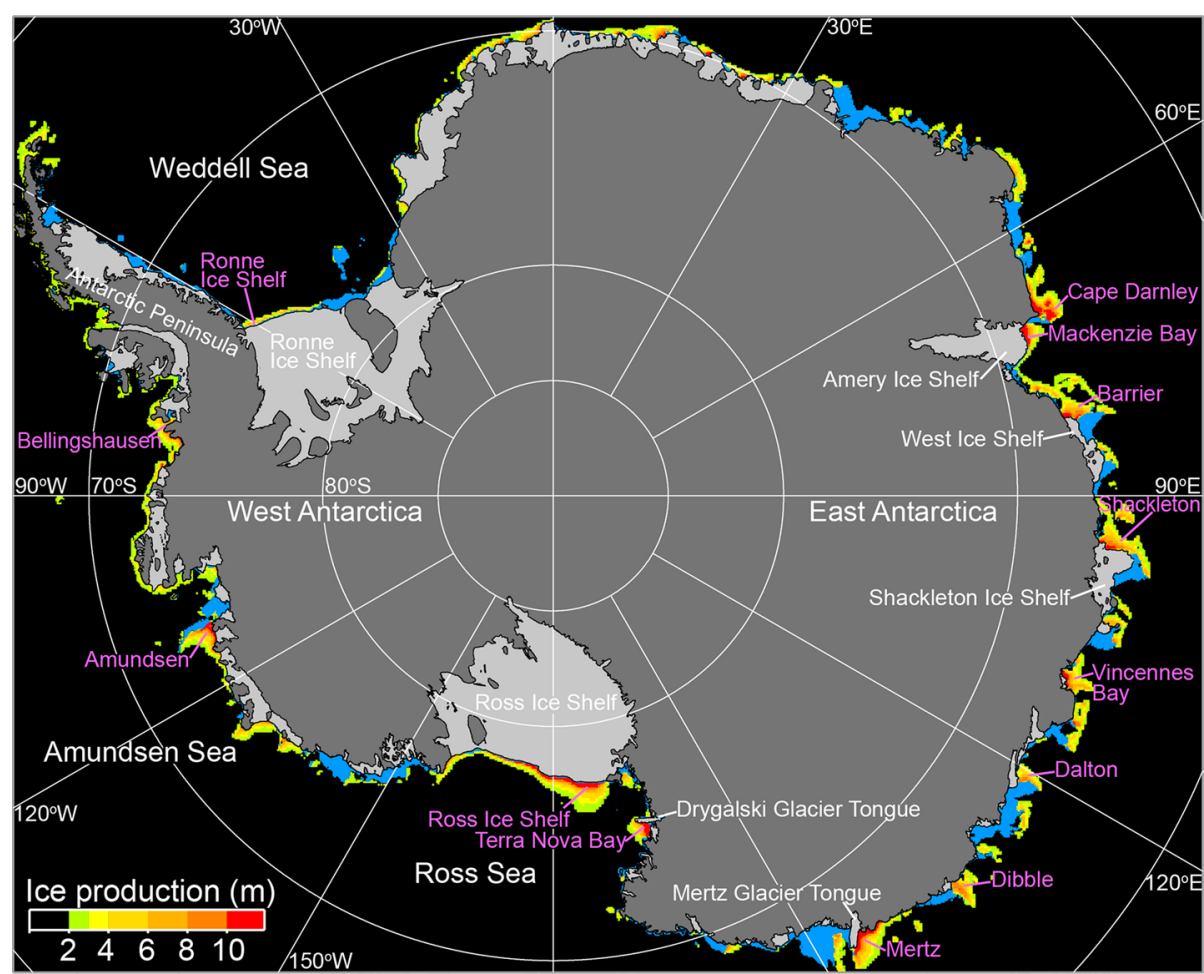

Fig. 3 Map of annual sea-ice production in the Southern Hemisphere. Sea-ice production cumulated from March to October is calculated, averaged over 2003-2010, based on the AMSR-E algorithm and atmospheric input data from ECMWF interim reanalysis dataset (Nihashi and Ohshima 2015). The fast ice areas shown in Fig. 2 are superimposed in sky blue

Prominent polynyas also occur along the Siberian coast south of the Bering Strait and along the Alaskan coast. Warner and Roden (1995) found high chlorofluorocarbon concentration in the abyssal layer of the Bering Sea, suggesting the possibility of temporary bottom water formation. The climatology of the bottom water over the Bering Shelf shows that saline and cold water extends from the Anadyr Gulf (Danielson et al. 2011). Therefore, bottom water formation, if it really occurs, might originate from high sea-ice production in the Anadyr Gulf.

As shown in the map of the polynya occurrence (Fig. 4), polynya activity is overall higher in the Sea of Okhotsk than in the Arctic Ocean, because of the dominance of divergent ice motion. In particular, the Okhotsk Northwestern polynya, driven by the prevailing northwesterly wind, is the largest polynya in the Northern Hemisphere (Martin et al. 1998; Kawaguchi et al. 2010). This northwesterly wind transports very cold air over the sea from the continent upwind, which recorded the lowest air temperature in the Northern Hemisphere and is called as "Cold Pole" (Nihashi et al. 2009). This makes the Okhotsk Northwestern polynya the highest sea-ice production polynya in the world (Table 1; Fig. 5), according to the present AMSR algorithm and definition of the polynya area (area with the production rate of $>3 \mathrm{~m} /$ year). High ice production in the Okhotsk coastal polynyas leads to large amounts of brine rejection, and DSW is subsequently formed (Shcherbina et al. 2003). The DSW is transported southward via the East Sakhalin Current (Fukamachi et al. 2004) and then mixed with intermediate water entering the sea from the North Pacific (Gladyshev et al. 2003) and thereby Okhotsk Sea Intermediate Water (OSIW) is formed. OSIW is considered the main ventilation source of the North Pacific Intermediate Water (Talley 1991; Warner et al. 1996; Shcherbina et al. 2003). In this way, sea-ice production in the Okhotsk coastal polynyas drives the overturning in the North Pacific down to intermediate depths (to approximately 200-800 m depths).

\section{Variability of bottom/intermediate water linked with ice production}

Changes in polynya ice production would substantially affect the DSW production, and thus AABW production. In the era prior to the large-scale estimation of seaice production from Tamura et al. (2008), the linkage between the ice production and AABW could not be discussed. Now that sea-ice production has been estimated 
Table 1 Annual cumulative sea-ice production for major coastal polynyas

\begin{tabular}{|c|c|c|}
\hline \multirow[t]{2}{*}{ Polynya } & \multirow{2}{*}{$\begin{array}{l}\text { Total ice } \\
\text { production }^{a} \\
\left(\mathrm{~km}^{3} / \text { year) }\right.\end{array}$} & \multirow{2}{*}{$\begin{array}{l}\text { Averaged ice } \\
\text { production }^{\text {b }} \\
\text { (m/year) }\end{array}$} \\
\hline & & \\
\hline \multicolumn{3}{|l|}{ Southern Hemisphere } \\
\hline Cape Darnley & $127 \pm 12$ & $8.2 \pm 0.8$ \\
\hline Mackenzie Bay & $57 \pm 5$ & $8.0 \pm 0.8$ \\
\hline Barrier & $58 \pm 7$ & $6.8 \pm 0.8$ \\
\hline Shackleton & $79 \pm 7$ & $6.5 \pm 0.6$ \\
\hline Vincenness Bay & $60 \pm 4$ & $6.9 \pm 0.5$ \\
\hline Dalton & $31 \pm 3$ & $5.7 \pm 0.5$ \\
\hline Dibble & $52 \pm 8$ & $6.1 \pm 0.9$ \\
\hline Mertz & $125 \pm 19$ & $7.6 \pm 1.2$ \\
\hline Terra Nova Bay & $53 \pm 5$ & $8.4 \pm 0.8$ \\
\hline Ross Ice Shelf & $253 \pm 17$ & $7.5 \pm 0.5$ \\
\hline Amundsen & $83 \pm 13$ & $6.6 \pm 1.0$ \\
\hline Bellingshausen & $52 \pm 12$ & $6.1 \pm 1.4$ \\
\hline Ronne Ice Shelf & $27 \pm 11$ & $4.7 \pm 1.9$ \\
\hline \multicolumn{3}{|l|}{ Northern Hemisphere } \\
\hline Storfjorden & $15 \pm 2$ & $4.0 \pm 0.5$ \\
\hline Franz Josef Land & $44 \pm 5$ & $4.0 \pm 0.5$ \\
\hline Novaya Zemlya & $71 \pm 16$ & $3.8 \pm 0.9$ \\
\hline Chukchi Sea & $25 \pm 7$ & $3.7 \pm 1.0$ \\
\hline Canadian Archipelago & $20 \pm 4$ & $4.2 \pm 0.7$ \\
\hline North Water (NOW) & $152 \pm 24$ & $5.3 \pm 0.8$ \\
\hline Northeast Water (NEW) & $15 \pm 6$ & $5.5 \pm 2.2$ \\
\hline Anadyr \& St. Lawrence & $140 \pm 27$ & $4.6 \pm 0.9$ \\
\hline Okhotsk Northwestern & $400 \pm 52$ & $4.7 \pm 0.6$ \\
\hline
\end{tabular}

Mean values are presented with their standard deviations. The calculation was performed for the 9 winters (September-May) of 2002/2003-2010/2011 in the Northern Hemisphere and for the nine winters (March-October) of 2003-2011 in the Southern Hemisphere, using ERA-interim data. The locations of the polynyas are indicated in Figs. 2, 3, 4, 5

a The cumulative production is integrated over the polynya area defined as the area of pixels with the annual ice production of $>3 \mathrm{~m} / \mathrm{yr}$

b The annual ice production, represented by ice thickness $(m)$, is averaged over the polynya area

globally, such discussion is possible and their strong linkage has been clarified.

The most prominent linkage recently found is the drastic change caused by the calving of the Mertz Glacier Tongue (MGT) in February 2010. This calving led to a substantial decrease in the Mertz polynya area and sea-ice production (Tamura et al. 2012). The most recent estimate (Nihashi and Ohshima 2015) showed that the amount of sea-ice production decreased by as much as $40 \%$, and the Mertz polynya dropped from the thirdlargest to the fifth-largest Antarctic ice production polynya. The hydrographic observations before and after the calving have clarified the significant reduction in dense water export and AABW (Aoki et al. 2013; Lacarra et al. 2014), which was also simulated and predicted in a numerical modeling study (Kusahara et al. 2011). Further, significant changes in biogeochemical conditions also occurred (Shadwick et al. 2013). Campagne et al. (2015), based on a 250-year long sediment core in this region, suggested that large and abrupt changes in local sea ice and bottom water conditions occur with a 70-year periodicity, associated with the MGT calving and regrowth dynamics. These demonstrate the strong linkage between the glacier tongue and $\mathrm{AABW}$ production.

High sea-ice production in the Cape Darnley polynya results from the ice barrier (grounded iceberg tongue) blocking the westward advection of sea ice. The change or collapse of the barrier can cause a pronounced change in sea ice and AABW production. Such a scenario can be applied to other high ice production polynyas which are potentially areas of AABW source. These imply that a drastic change in fast ice extent, which is vulnerable to climate change (Fraser et al. 2012), causes dramatic changes in the polynyas and possibly AABW formation that can potentially contribute to further climate change.

One of the striking facts recently revealed in the Antarctic is that the AABW is significantly warming in a circumpolar domain (Purkey and Johnson 2010; Kouketsu et al. 2011), and freshening at least in Ross Sea and Australian-Antarctic Basin (Aoki et al. 2005; Rintoul 2007; Katsumata et al. 2015; Purkey and Johnson 2013). Globally, warming of deep water is by far the most dominant in the Southern Ocean, particularly near the sea floor where the AABW influence is strongest (Purkey and Johnson 2010; Rhein et al. 2013). This warming and freshening suggest the contraction of AABW (Purkey and Johnson 2012; van Wijk and Rintoul 2014), which will potentially result in weakening of global thermohaline circulation. The other striking fact recently revealed in the Antarctic is that mass loss from Antarctic ice shelves is accelerating in West Antarctica (Rignot et al. 2013; Pritchard et al. 2012; Paolo et al. 2015). Recent freshening of AABW can be partly explained by this enhanced melting of ice shelves (Purkey and Johnson 2013). On the other hand, numerical model simulations (e.g., Kusahara and Hasumi 2013) suggest that sea-ice production in the coastal polynyas controls the onshore intrusion of warm Circumpolar Deep Water and thus melting of the ice shelves. All these findings suggest that precise polynya processes should be addressed by next-generation models to produce more accurate climate projections, particularly on a longer time scale.

The change in bottom/intermediate water would affect the thermohaline circulation on a longer timescale, and thus the linkage between sea-ice production and bottom/ intermediate water is quite an important issue in climate 


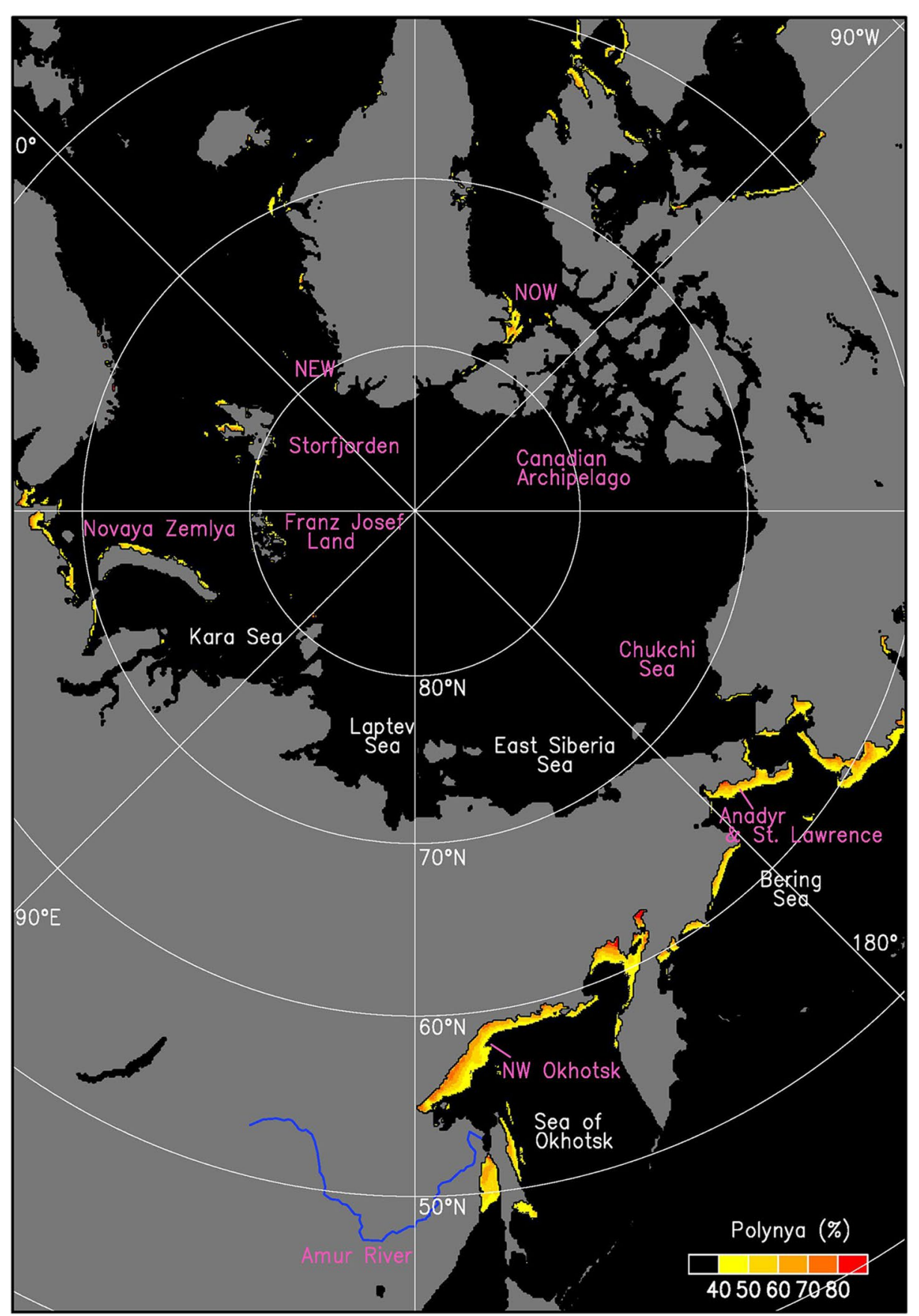

Fig. 4 Map of coastal polynyas in the Northern Hemisphere. The calculation is based on thin-ice thickness algorithm of AMSR-E (Iwamoto et al. 2013 , 2014). Frequency of occurrence during the freezing period (September-May) of 2002/2003-2010/2011 is shown by color shadings, with the same color scale as that of Fig. 2 (Southern Hemisphere)

change. The SSM/I data have the advantage of longer record period, over more than 20 years, while the disadvantage is their low spatial resolution, when compared to AMSR-E. Quantitative comparison of SSM/I and AMSRE data and their combined study would partly overcome the disadvantage, which will enable us to conduct climatechange related analyses. The linkage between sea-ice production and bottom/intermediate water on a longer timescale has just begun to be discussed. A prominent linkage has been revealed in the Sea of Okhotsk as follows. 


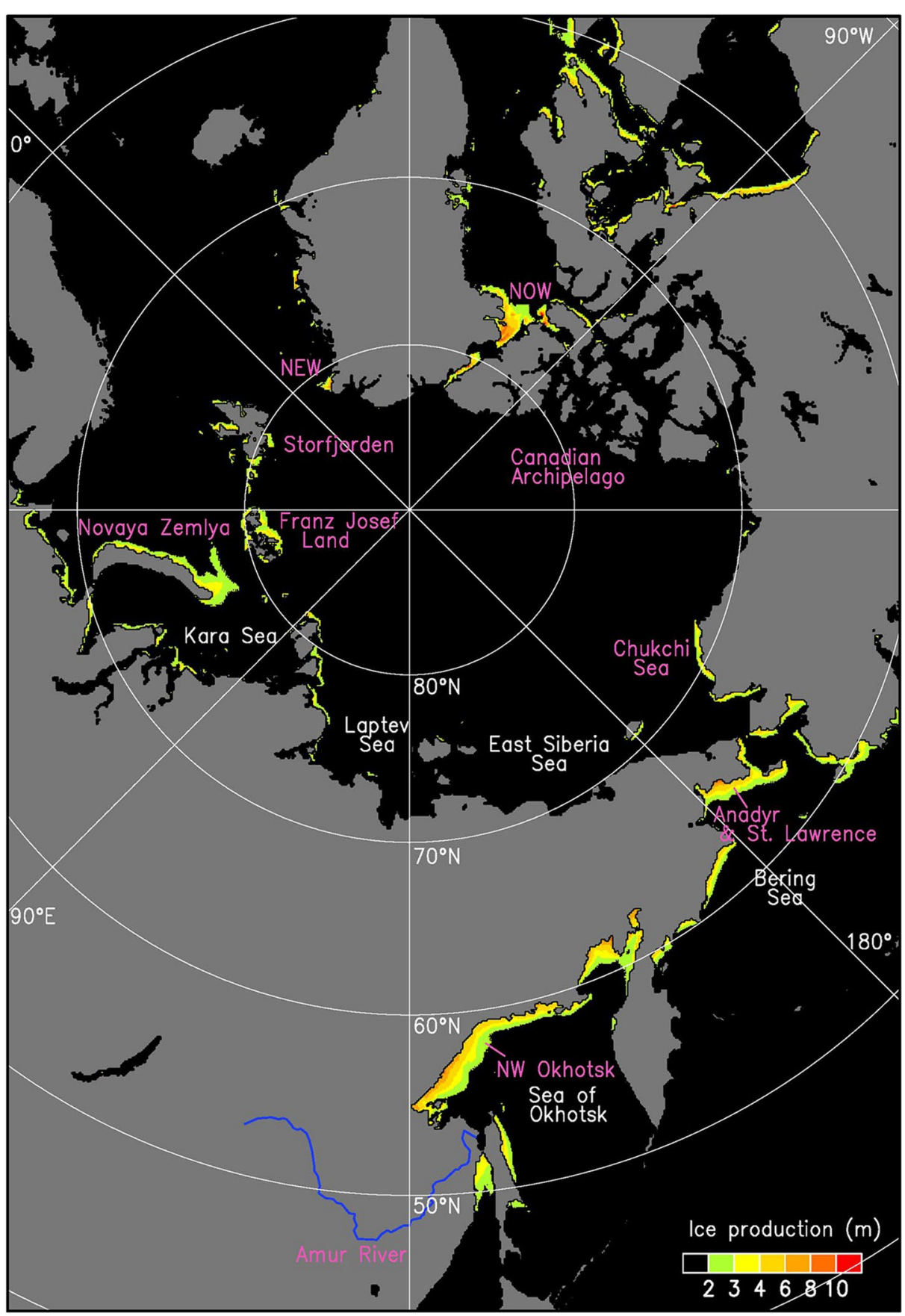

Fig. 5 Map of annual sea-ice production in the Northern Hemisphere. Sea-ice production cumulated from September to May is calculated, averaged over 2002/2003-2010/2011, based on the AMSR-E algorithm and atmospheric input data from ECMWF interim reanalysis dataset (Iwamoto et al. 2013, 2014). The color scale is the same as that of Fig. 3 (Southern Hemisphere)

During the past 50 years, the intermediate layer (between 26.8 and $27.0 \sigma_{\theta}$ isopycnal surfaces) in the North Pacific has warmed, and its dissolved oxygen content has decreased (Ono et al. 2001; Nakanowatari et al. 2007). These changes likely originated in the Sea of Okhotsk, and weakening of the overturning in the North
Pacific is suggested (Nakanowatari et al. 2007). Kashiwase et al. (2014) made careful comparison of AMSR-E and SSM/I data and discussed the longer term variability on ice production in the Okhotsk Sea. The annual ice production from 1974 to 2008 was estimated based on heat flux calculation from SSM/I-derived ice thickness 
and key atmospheric parameters that control the ice production. The reconstructed ice production shows a significant decreasing trend of $11.4 \%$ over 34 years, which is mainly explained by the warming of autumn air temperature in the northwest of the Okhotsk. Further, the variation of the ice production is found to be linked with that of the OSIW property (low ice production corresponds to high OSIW temperatures). This first observational evidence of a linkage between the annual ice production and OSIW supports a hypothesis that decreasing ice production in the Okhotsk coastal polynyas, at least in part, has led to weakening of the overturning in the North Pacific.

\section{Discussion}

\section{Improvement of the algorithm}

Although the satellite passive microwave dataset is a strong tool for obtaining the spatial distribution of seaice production on a large scale, the estimated ice production has relatively large uncertainty in its absolute value, because of ambiguity in the satellite-derived ice thickness, to which the estimation has the highest sensitivity among all the input data (Nihashi and Ohshima 2015; Iwamoto et al. 2014). The relationship between PR and thermal ice thickness depends to some degree on the region. Such differences probably arise from a dominant sea-ice type (e.g., frazil ice, grease ice, or nilas) in each region. The dominant sea-ice type would be determined by local atmospheric and geographical conditions such as the wind speed and surface air temperature. Development of a more generalized or unified algorithm remains for future work. For a more reliable algorithm, comparison and validation with ice thickness data by in situ observations will be ultimately required, although such observations in the polynya areas have been quite limited until now. To validate and improve the estimation of heat flux or ice production from the algorithm, comparison with airborne observations over the polynya area (e.g., Roberts et al. 2001; Fiedler et al. 2010; Tamura et al. 2015) will be very effective. In these validations, the difference in scale from the satellite footprint should be taken into consideration.

\section{Impact on material cycle and biological productivity}

When dense water sinks to deep or intermediate layers, various kinds of materials are also transported. Of particular interest is iron, which is considered the key element in determining biological productivity (Martin and Fitzwater 1989). Thus, the overturning can contribute to the material cycle and subsequent biological productivity through the supply of nutrients such as iron. It has been recently revealed in the Sea of Okhotsk that when DSW formed by the polynya ice production sinks to the intermediate layer, re-suspended iron from sediment over the continental shelf is also brought to this layer (Nishioka et al. 2013). The iron is considered to originate from the land through the Amur River. One hypothesis says that the iron from DSW is also supplied to the western area of the North Pacific and supports high biological productivity there (Nishioka et al. 2013). As such, the land or the Amur River possibly feeds the ocean through the supply of iron in the western North Pacific. This system is termed the "Giant Fish-Breeding Forest" (Shiraiwa 2012). As described, over the past $30-50$ years, polynya ice production and accordingly DSW production have declined in the Sea of Okhotsk, thereby weakening the overturning at the North Pacific. Thus, the following scenario might be possible: Decline of sea ice and DSW production due to the global warming decreases the iron supply in the North Pacific as well as in the Sea of Okhotsk, thereby reducing levels of biological productivity and fishery resources.

\section{Dataset of heat/salt flux associated with ice production/ melt}

Sea-ice formation, its transport, and its melting cause the redistribution of heat and salt, which plays an important role in the climate and biogeochemical systems. In the formation area, sea ice loses latent heat to the atmosphere and releases salt into the ocean, whereas in the melting area, sea ice gains latent heat from the atmosphere and releases freshwater into the ocean. The estimates of sea-ice production are based on calculation of heat flux with the assumption of no oceanic heat flux, as described. Thus, this estimation can be converted into the estimate of heat/salt fluxes associated with sea-ice formation (lower part of Fig. 1). We will be able to obtain the net heat/salt fluxes associated with sea-ice processes, if we can also estimate the heat/salt fluxes associated with sea-ice melting, which is more difficult to calculate.

Tamura et al. (2011) presented the first investigation that creates a dataset of heat/salt fluxes, both by seaice production and melting on a hemispherical scale (Southern Ocean). In that study, the amount of melting ice is calculated from the daily decrease in SSM/I sea-ice concentration, taking account of the effect of ice drift and heat flux. The thickness of the melting ice is adjusted so that the total ice melting is balanced by the total ice production in the entire Southern Ocean. That study demonstrates that sea ice formed via losing latent heat with salt release in the coastal regions is transported offshore, where it gains latent heat from the atmosphere and releases freshwater by melting. Annual cumulative heat and salt contents show a large heat loss $\left(11 \times 10^{20} \mathrm{~J}\right)$ and salt release $\left(64 \times 10^{12} \mathrm{~kg}\right)$ in the coastal regions. This 
$64 \times 10^{12} \mathrm{~kg}$ of annual cumulative salt content implies that $\sim 1900 \mathrm{Gt} / \mathrm{yr}$ of freshwater is supplied to the region outside of the coastal zone. This value is comparable to the annual ice loss from the Antarctic Ice Sheet (Rignot et al. 2013).

A similar heat/salt flux data set was created for the Sea of Okhotsk, using AMSR-E ice concentration, thin-ice thickness and ice drift data (Nihashi et al. 2012). The spatial distribution of the annual fluxes shows the significant ocean cooling with salt supply in the northern coastal polynya region, while ocean heating with freshwater supply in the south. This clearly demonstrates the role of sea-ice formation/melting with its prominent southward transport by the prevailing northerly wind and current (Fukamachi et al. 2009; Simizu et al. 2014) on redistribution of heat and salt. It is pointed out that this redistribution system by sea ice has weakened. A recently constructed hydrographic dataset from the Okhotsk Sea reveals a prominent freshening to depths of $500 \mathrm{~m}$ during the past four decades, with the maximum in the northwestern part of the sea (Ohshima et al. 2014). It is proposed that the freshening is caused by the weakening of salt/freshwater redistribution through a decrease in sea-ice production. In conjunction with a recent freshening in high latitude oceans, previous studies have mainly examined changes in the enhanced global hydrological cycle due to changes in net evaporation and precipitation (Durack et al. 2012). It is demonstrated that sea-ice decline can be an important contributor to freshening in ice-covered regions of the world ocean.

These large-scale datasets of heat/salt fluxes associated with sea-ice growth and melt will provide new information with which to validate ice-ocean (and ice-oceanatmosphere) coupled models while providing important boundary conditions for the various models, particularly because the redistribution of heat and salt-freshwater contents by sea ice is quite important for thermohaline circulation in the ocean (e.g., Komuro and Hasumi 2003; Marsland and Wolff 2001). Some of the datasets for ice production and heat/salt fluxes using microwave data are now archived at the website of the Institute of Low Temperature Science, Hokkaido University (http://wwwod. lowtem.hokudai.ac.jp/polar-seaflux). These datasets have been used for validating the ice-ocean coupled models. The flux dataset can also be used as surface boundary conditions for ice-covered seas in ocean general circulation models. Once the heat and salt flux data associated with ice production and melting are given, ocean circulation models can represent the thermohaline circulation caused by ice formation, even without a sea ice model. Actually, these flux data sets have been used as the surface boundary conditions for several numerical models that reproduce AABW formation (e.g., Galton-Fenzi et al. 2012; Nakayama et al. 2014).

\section{Conclusions}

Mapping of coastal polynya and sea-ice production is presented with the same definition and scale globally, based on satellite-derived ice thickness and heat flux calculations by Nihashi and Ohshima (2015) and Iwamoto et al. (2014). The mapping demonstrates the strong linkage between sea-ice production and bottom/intermediate water formation. Antarctic coastal polynyas generally show high ice production due to dominance of divergent ice motion, particularly on the lee side of landfast ice or glacier tongues. The Ross Ice Shelf polynya has by far the highest ice production in the Southern Hemisphere, consistent with formation area of saline AABW. The Cape Darnley polynya $\left(65^{\circ} \mathrm{E}-69^{\circ} \mathrm{E}\right)$, the second highest ice production area, was recently found to be the missing (fourth) source of AABW in the East Antarctica. In the Mertz polynya, the third highest ice production area, the production decreased by as much as $40 \%$, due to the MGT calving in early 2010, resulting in a significant decrease of AABW production. The Okhotsk Northwestern polynya exhibits the highest ice production in the Northern Hemisphere, and the resultant dense water formation leads to the overturning in the North Pacific. Its ice production shows a significant decrease over the past 30-50 years, likely causing the weakening of North Pacific overturning. When compared to the Southern Ocean and the Sea of Okhotsk, Arctic polynyas generally show much lower ice production, because the surrounding land suppresses the divergent ice motion. Fairly high ice production occurs in the Anadyr Gulf and St. Lawrence Island polynyas, providing the possibility of temporary bottom water formation in the Bering Sea.

\section{Abbreviations \\ AABW: Antarctic Bottom Water; MGT: Mertz Glacier Tongue; NADW: North Atlantic Deep Water; DSW: dense shelf water; SSM/l: special sensor micro- wave/imager; AMSR-E: Advanced Microwave Scanning Radiometer-Earth Observing System; PR: polarization ratio; TB: brightness temperature; AVHRR: Advanced Very High-Resolution Radiometer; MODIS: Moderate Resolution Imaging Spectroradiometer; PSSM: Polynya Signature Simulation Method; CDBW: Cape Darnley Bottom Water; NOW: North Water; OSIW: Okhotsk Sea Intermediate Water.}

\section{Authors' contributions}

This paper was presented by KO as a "Distinguished Lecture" at the 2014 AOGS Meeting held in Sapporo, Japan. KO drafted the manuscript. SN carried out calculation and analyses of sea ice production for the part of the Southern Hemisphere, while Kl carried out the calculation and analyses for the part of the Northern Hemisphere. All authors read and approved the final manuscript.

\section{Author details \\ ${ }^{1}$ Institute of Low Temperature Science, Hokkaido University, Sapporo, Japan. ${ }^{2}$ Department of Engineering for Innovation, National Institute of Technology, Tomakomai College, Tomakomai, Japan. ${ }^{3}$ Faculty of Science, Niigata Univer- sity, Niigata, Japan.}

\section{Acknowledgements}

The AMSR-E data were provided by the National Snow and Ice Data Center, University of Colorado. We thank Alexander D. Fraser for his valuable 
comments on the manuscript, Takeshi Tamura for helping with the development of the algorithms, and Kyoko Kitagawa for preparation of the manuscript. This work was supported by Grants-in-Aids for Scientific Research (20221001, 21740337, 24740322, and 25241001) of the Ministry of Education, Culture, Sports, Science and Technology in Japan. This work was also supported by a Japan Aerospace Exploration Agency research fund for Global Change Observation Mission-Water 1.

\section{Competing interests}

The authors declare that they have no competing interests.

Received: 2 August 2015 Accepted: 21 April 2016

Published online: 12 May 2016

\section{References}

Aagaard K, Coachman L, Carmack E (1981) On the halocline of the Arctic Ocean. Deep-Sea Res A 28:529-545

Aoki S, Rintoul SR, Ushio S, Watanabe S, Bindoff NL (2005) Freshening of the Adélie Land Bottom Water near 140E. Geophys Res Lett 32:L23601

Aoki S, Kitade Y, Shimada K, Ohshima Kl, Tamura T, Bajish CC, Moteki M, Rintoul SR (2013) Widespread freshening in the Seasonal Ice Zone near $140^{\circ} \mathrm{E}$ off the Adélie Land Coast, Antarctica, from 1994 to 2012. J Geophys Res 118:6046-6063

Arrigo KR, van Dijken GL (2003) Phytoplankton dynamics within 37 Antarctic coastal polynya systems. J Geophys Res 108:3271

Barber DG, Massom RA (2007) The role of sea ice in Arctic and Antarctic polynyas. In: Smith WO Jr, Barber DG (eds) Polynyas: windows to the world. Elsevier Oceanography Series, vol 74. Elsevier, Amsterdam, pp 1-54

Campagne P, Crosta X, Houssais MN, Swingedouw D, Schmidt S, Martin A, Devred E, Capo S, Marieu V, Closset I, Masse' G (2015) Glacial ice and atmospheric forcing on the Mertz Glacier Polynya over the past 250 years. Nat Commun 6:6642

Cavalieri DJ (1994) A microwave technique for mapping thin sea ice. J Geophys Res 99:12561-12572

Cavalieri DJ, Martin S (1985) A passive microwave study of polynyas along the Antarctic Wilkes Land coast. In: Jacobs S (ed) Oceanology of the Antarctic Continental Shelf. Antarctic Research Series, vol 43. American Geophysical Union, Washington, pp 227-252

Cavalieri DJ, Martin S (1994) The contribution of Alaskan, Siberian, and Canadian coastal polynyas to the cold halocline layer of the Arctic Ocean. J Geophys Res 99:18343-18362

Comiso JC, Kwok R, Martin S, Gordon AL (2011) Variability and trends in sea ice extent and ice production in the Ross Sea. J Geophys Res 116:C04021

Cox GFN, Weeks WF (1974) Salinity variations in sea ice. J Glaciol 13:109-120

Danielson S, Curchitser E, Hedstrom K, Weingartner T, Stabeno P (2011) On ocean and sea ice modes of variability in the Bering Sea. J Geophys Res 116:C12034

Drucker R, Martin S, Moritz R (2003) Observations of ice thickness and frazil ice in the St. Lawrence Island polynya from satellite imagery, upward looking sonar, and salinity/temperature moorings. J Geophys Res 108:3149

Drucker R, Martin S, Kwok R (2011) Sea ice production and export from coastal polynyas in the Weddell and Ross Seas. Geophys Res Lett 38:L17502

Durack PJ, Wijffels SE, Matear RJ (2012) Ocean salinities reveal strong global water cycle intensification during 1950 to 2000. Science 336:455-458

Fiedler EK, Lachlan-Cope TA, Renfrew IA, King JC (2010) Convective heat transfer over thin ice covered coastal polynyas. J Geophys Res 115:C10051

Foldvik A, Gammelsrød T, Østerhus S, Fahrbach E, Rohardt G, Schröder M, Nicholls KW, Padman L, Woodgate RA (2004) Ice shelf water overflow and bottom water formation in the southern Weddell Sea. J Geophys Res 109:C02015

Fraser AD, Massom RA, Michael KJ, Galton-Fenzi BK, Lieser JL (2012) East Antarctic landfast sea ice distribution and variability, 2000-08. J Clim 25:1137-1156

Fukamachi Y, Mizuta G, Ohshima Kl, Talley LD, Riser SC, Wakatsuchi M (2004) Transport and modification processes of dense shelf water revealed by long-term moorings off Sakhalin in the Sea of Okhotsk. J Geophys Res 109:C09S10
Fukamachi Y, Shirasawa K, Polomoshnov AM, Ohshima Kl, Kalinin E, Nihashi S, Melling H, Mizuta G, Wakatsuchi M (2009) Direct observations of sea-ice thickness and brine rejection off Sakhalin in the Sea of Okhotsk. Cont Shelf Res 29:1541-1548

Fusco G, Budillon G, Spezie G (2009) Surface heat fluxes and thermohaline variability in the Ross Sea and in Terra Nova Bay polynya. Cont Shelf Res 29:1887-1895

Galton-Fenzi BK, Hunter JR, Coleman R, Marsland SJ, Warner R (2012) Numerical modelling of melt/freeze beneath the Amery Ice Shelf. J Geophys Res 117:C09031

Gladyshev S, Talley LD, Kantakov G, Khen G, Wakatsuchi M (2003) Distribution, formation, and seasonal variability of Okhotsk Sea Mode Water. J Geophys Res 108:3186

Gordon AL, Comiso JC (1988) Polynyas in the Southern Ocean. Sci Am 258:90-97

Hwang BJ, Ehn JK, Barber DG, Galley R, Grenfell TC (2007) Investigations of newly formed sea ice in the Cape Bathurst polynya: 2 microwave emission. J Geophys Res 112:C05003

Iwamoto K, Ohshima KI, Tamura T, Nihashi S (2013) Estimation of thin ice thickness from AMSR-E data in the Chukchi Sea. Int J Remote Sens 34:468-489

Iwamoto K, Ohshima Kl, Tamura T (2014) Improved mapping of sea ice production in the Arctic Ocean using AMSR-E thin ice thickness algorithm. J Geophys Res 119:3574-3594

Johnson GC (2008) Quantifying Antarctic Bottom Water and North Atlantic Deep Water volumes. J Geophys Res 113:C05027

Jullion L, Garabato ACN, Bacon S, Meredith MP, Brown PJ, Torres-Valdes S, Speer KG, Holland PR, Dong J, Bakker D, Hoppema M, Loose B, Venables HJ, Jenkins WJ, Messias M-J, Fahrbach E (2014) The contribution of the Weddell Gyre to the lower limb of the Global Overturning Circulation. J Geophys Res 119:3357-3377

Kashiwase H, Ohshima Kl, Nihashi S (2014) Long-term variation in sea ice production and its relation to the intermediate water in the Sea of Okhotsk. Prog Oceanogr 126:21-32

Katsumata K, Nakano H, Kumamotoa Y (2015) Dissolved oxygen change and freshening of Antarctic Bottom Water along $62^{\circ} \mathrm{S}$ in the Australian-Antarctic Basin between 1995/1996 and 2012/2013. Deep-Sea Res II 114:27-38

Kawaguchi Y, Nihashi S, Mitsudera H, Ohshima KI (2010) Formation mechanism of huge coastal polynyas and its application to Okhotsk Northwestern Polynya. J Phys Oceanogr 40:2451-2465

Kern S (2009) Wintertime antarctic coastal polynya area: 1992-2008. Geophys Res Lett 36:L14501

Kitade Y, Shimada K, Tamura T, Williams GD, Aoki S, Fukamachi Y, Roquet F, Hindell M, Ushio S, Ohshima KI (2014) Antarctic Bottom Water production from the Vincennes Bay Polynya, East Antarctica. Geophys Res Lett 41:3528-3534

Komuro Y, Hasumi H (2003) Effects of surface freshwater flux induced by sea ice transport on the global thermohaline circulation. J Geophys Res 108:3047

Kouketsu S, Doi T, Kawano T, Masuda S, Sugiura N, Sasaki Y, Toyoda T, Igarashi H, Kawai Y, Katsumara K, Uchida H, Fukusawa M, Awaji T (2011) Deep ocean heat content changes estimated from observation and reanalysis product and their influence on sea level change. J Geophys Res 116:C03012

Kurtz NT, Markus T (2012) Satellite observations of Antarctic sea ice thickness and volume. J Geophys Res 117:C08025

Kusahara K, Hasumi H (2013) Modeling Antarctic ice shelf responses to future climate changes and impacts on the ocean. J Geophys Res $118: 2454-2475$

Kusahara K, Hasumi H, Williams GD (2011) Impact of the Mertz Glacier Tongue calving on dense water formation and export. Nat Commun 2:159

Lacarra M, Houssais MN, Herbaut C, Sultan E, Beauverger M (2014) Dense shelf water production in the Adélie Depression, East Antarctica, 2004-2012: impact of the Mertz Glacier calving. J Geophys Res 119:5203-5220

Markus T, Burns BA (1995) A method to estimate subpixel-scale coastal polynyas with satellite passive microwave data. J Geophys Res 100:4473-4487

Markus T, Kottmeier C, Fahrbach E (1998) Ice formation in coastal polynyas in the Weddell Sea and their impact on oceanic salinity. In: Jeffries MO (ed) Antarctic Sea Ice: Physical Processes, Interactions and Variability. Antarctic Research Series, vol 74. AGU, Washington, pp 273-292

Marsland SJ, Wolff J-O (2001) On the sensitivity of Southern Ocean sea ice to the surface freshwater flux: a model study. J Geophys Res 106:2723-2741 
Martin S (2001) Polynyas. In: Encyclopedia of Ocean Sciences, vol 3. Academic Press, London, pp 2241-2247

Martin JH, Fitzwater SE (1989) Iron deficiency limits phytoplankton growth in the north-east Pacific subarctic. Nature 331:341-343

Martin S, Drucker R, Yamashita K (1998) The production of ice and dense shelf water in the Okhotsk Sea polynyas. J Geophys Res 103:27771-27782

Martin S, Drucker R, Kwok R, Holt B (2004) Estimation of the thin ice thickness and heat flux for the Chukchi Sea Alaskan coast polynya from Special Sensor Microwave/Imager data, 1990-2001. J Geophys Res 109:C10012

Martin S, Drucker RS, Kwok R (2007) The areas and ice production of the western and central Ross Sea polynyas, 1991-2002, and their relation to the B-15 and C-19 iceberg events of 2000 and 2002. J Mar Syst 68:201-214

Massom RA, Harris PT, Michael KJ, Potter MJ (1998) The distribution and formative processes of latent-heat polynyas in East Antarctica. Ann Glaciol 27:420-426

Morales Maqueda MA, Willmott AJ, Biggs NRT (2004) Polynya dynamics: a review of observations and modeling. Rev Geophys 42:RG1004

Nakanowatari T, Ohshima Kl, Wakatsuchi M (2007) Warming and oxygen decrease of intermediate water in the northwestern North Pacific, originating from the Sea of Okhotsk, 1955-2004. Geophys Res Lett 34:L04602

Nakata K, Ohshima KI, Nihashi S, Kimura N, Tamura T (2015) Variability and ice production budget in the Ross Ice Shelf Polynya based on a simplified polynya model and satellite observations. J Geophys Res 120:6234-6252

Nakayama Y, Ohshima KI, Matsumura Y, Fukamachi Y, Hasumi H (2014) A numerical investigation of formation and variability of Antarctic Bottom Water off Cape Darnley, East Antarctica. J Phys Oceanogr 44:2921-2937

Nihashi S, Ohshima KI (2015) Circumpolar mapping of Antarctic coastal polynyas and landfast sea ice: relationship and variability. J Clim 28:3650-3670

Nihashi S, Ohshima KI, Tamura T, Fukamachi Y, Saitoh S (2009) Thickness and production of sea ice in the Okhotsk Sea coastal polynyas from AMSR-E. J Geophys Res 114:C10025

Nihashi S, Ohshima Kl, Kimura N (2012) Creation of a heat and salt flux dataset associated with sea ice production and melting in the Sea of Okhotsk. J Clim 25:2261-2278

Nishioka J, Nakatsuka T, Watanabe YW, Yasuda I, Kuma K, Ogawa H, Ebuchi N, Scherbinin A, Volkov YN, Shiraiwa T, Wakatsuchi M (2013) Intensive mixing along an island chain controls oceanic biogeochemical cycles. GBC 27:1-10

Ohshima KI, Watanabe T, Nihashi S (2003) Surface heat budget of the Sea of Okhotsk during 1987-2001 and the role of sea ice on it. J Meteorol Soc Jpn 81:653-677

Ohshima KI, Fukamachi Y, Williams GD, Nihashi S, Roquet F, Kitade Y, Tamura T, Hirano D, Herraiz-Borreguero L, Field I, Hindell M, Aoki S, Wakatsuchi M (2013) Antarctic Bottom Water production by intense sea-ice formation in the Cape Darnley Polynya. Nat Geo 6:235-240

Ohshima KI, Nakanowatari T, Riser S, Volkov Y, Wakatsuchi M (2014) Freshening and dense shelf water reduction in the Okhotsk Sea linked with sea ice decline. Prog Oceanogr 126:71-79

Ono T, Midorikawa T, Watanabe YW, Tadokoro K, Saino T (2001) Temporal increases of phosphate and apparent oxygen utilization in the surface waters of western subarctic Pacific from 1968 to 1998. Geophys Res Lett 28:3285-3288

Orsi AH, Johnston GC, Bullister JB (1999) Circulation, mixing and production of Antarctic Bottom Water. Prog Oceanogr 43:55-109

Orsi AH, Smethie WM Jr, Bullister JL (2002) On the total input of Antarctic waters to the deep ocean: a preliminary estimate from chlorofluorocarbon measurements. J Geophys Res 107:3122

Paolo FS, Fricker HA, Padman L (2015) Volume loss from Antarctic ice shelves is accelerating. Science 348:327-331

Pease CH (1987) The size of wind-driven coastal polynyas. J Geophys Res 92:7049-7059

Pritchard HD, Ligtenberg SRM, Fricker HA, Vaughan DG, van den Broeke MR, Padman L (2012) Antarctic ice-sheet loss driven by basal melting of ice shelves. Nature 484:502-505

Purkey SG, Johnson GC (2010) Warming of global abyssal and deep Southern Ocean waters between the 1990s and 2000s: contributions to global heat and sea level rise budgets. J Clim 23:6336-6351

Purkey SG, Johnson GC (2012) Global contraction of Antarctic Bottom Water between the 1980s and 2000s. J Clim 25:5830-5844

Purkey SG, Johnson GC (2013) Antarctic Bottom Water warming and freshening: contributions to sea level rise, ocean freshwater budgets, and global heat gain. J Clim 26:6105-6122
Rhein M, Rintoul SR, Aoki S, Campos E, Chambers D, Feely RA, Gulev S, Johnson GC, Josey SA, Kostianoy A, Mauritzen C, Roemmich D, Talley LD, Wang F (2013) Observations Ocean. In: Stocker TF et al (eds) Climate Change 2013: The Physical Science Basis. Contribution of Working Group I to the Fifth Assessment Report of the Intergovernmental Panel on Climate Change. Cambridge University Press, Cambridge, pp 255-297

Rignot E, Jacobs SS, Mouginot J, Scheuchl B (2013) Ice shelf melting around Antarctica. Science 341:266-270

Rintoul SR (1998) On the origin and influence of Adélie Land Bottom Water. In: Jacobs SS, Weiss RF (eds) Interactions at the Antarctic Continental Margin. Antarctic Research Series, vol 75. American Geophysical Union, Washington, pp 151-171

Rintoul SR (2007) Rapid freshening of Antarctic Bottom Water formed in the Indian and Pacific oceans. Geophys Res Lett 34:L06606

Roberts A, Allison I, Lytle VI (2001) Sensible- and latent-heat-flux estimates over the Mertz Glacier polynya, East Antarctica, from in-flight measurements. In: Jeffries MO, Eicken $\mathrm{H}$ (eds) Annals of Glaciology, vol 33. IGS, Cambridge, pp 377-384

Scott KA, Buehner M, Carrieres T (2014) An assessment of sea-ice thickness along the Labrador coast from AMSR-E and MODIS data for operational data assimilation. IEEE Trans Geosci Remote Sens 52:2726-2737

Shadwick E, Rintoul SR, Tilbrook B, Williams GD, Young N, Fraser AD, Marchant H, Smith J, Tamura T (2013) Glacier tongue calving reduced dense water formation and enhanced carbon uptake. Geophys Res Lett 40:904-909

Shcherbina AY, Talley LD, Rudnick DL (2003) Direct observations of North Pacific ventilation: brine rejection in the Okhotsk Sea. Science 302:1952-1955

Shiraiwa T (2012) "Giant Fish-Breeding Forest": a new environmental system linking continental watershed with open water. In: Taniguchi M, Shiraiwa $\mathrm{T}$ (eds) The Dilemma of Boundaries, Towards a New Concept of Catchment. Springer, New York, pp 73-85

Sigman DM, Boyle EA (2000) Glacial/interglacial variations in atmospheric carbon dioxide. Nature 407:859-869

Simizu D, Ohshima Kl, Ono J, Fukamachi Y, Mizuta G (2014) What drives the southward drift of sea ice in the Sea of Okhotsk? Prog Oceanogr 126:33-43

Steffen K (1986) Ice conditions of an Arctic polynya: North Water in winter. J Glaciol 32(112):383-390

Talley LD (1991) An Okhotsk Sea water anomaly: implications for ventilation in the North Pacific. Deep-Sea Res A 38(supplement):S171-S190

Tamura T, Ohshima KI (2011) Mapping of sea ice production in the Arctic coastal polynyas. J Geophys Res 116:C07030

Tamura T, Ohshima Kl, Markus T, Cavalieri DJ, Nihashi S, Hirasawa N (2007) Estimation of thin ice thickness and detection of fast ice from SSM/I data in the Antarctic Ocean. J Atmos Oceanic Technol 24:1757-1772

Tamura T, Ohshima KI, Nihashi S (2008) Mapping of sea ice production for Antarctic coastal polynyas. Geophys Res Lett 35:L07606

Tamura T, Ohshima Kl, Nihashi S, Hasumi H (2011) Estimation of surface heat/ salt fluxes associated with sea ice growth/melt in the Southern Ocean. SOLA 7:17-20

Tamura T, Williams GD, Fraser AD, Ohshima KI (2012) Potential regime shift in decreased sea ice production after the Mertz Glacier calving. Nat Commun 3:826

Tamura T, Ohshima KI, Lieser JL, Toyota T, Tateyama K, Nomura D, Nakata K, Fraser AD, Jansen PW, Newbery KB, Massom RA, Ushio S (2015) Helicopter-borne observations with portable microwave radiometer in the Southern Ocean and the Sea of Okhotsk. Ann Glaciol 56(69):436-444

Toyota T, Takatsuji S, Tateyama K, Naoki K, Ohshima KI (2007) Properties of sea ice and overlying snow in the southern Sea of Okhotsk. J Oceanogr 63:393-411

van Wijk EM, Rintoul SR (2014) Freshening drives contraction of Antarctic Bottom Water in the Australian Antarctic Basin. Geophys Res Lett 41:1657-1664

Warner MJ, Roden GI (1995) Chlorofluorocarbons evidence for recent ventilation of the deep Bering Sea. Nature 373:409-412

Warner MJ, Bullister UL, Wisegraver DP, Gammon RH, Weiss RF (1996) Basinwide distributions of chlorofluorocarbons CFC-11 and CFC-12 in the North Pacific. J Geophys Res 101:20525-20542

Williams GD, Bindoff NL, Marsland SJ, Rintoul SR (2008) Formation and export of dense shelf water from the Adélie Depression East Antarctica. J Geophys Res 113:C04039

Winsor P, Bjork G (2000) Polynya activity in the Arctic Ocean from 1958 to 1997. J Geophys Res 105:8789-8803 